\title{
PROCES KSZTALTOWANIA SIĘ NARODU MACEDOŃSKIEGO WOBEC SKOMPLIKOWANEJ SYTUACJI GEOPOLITYCZNEJ
}

UWAGI WSTĘPNE

W połowie czerwca 2011 roku na Placu Macedońskim w Skopje stanął pomnik Aleksandra Macedońskiego. Konstrukcja wraz z betonową fontanną, na której umieszczono monument, mierzyła 24 metry wysokości, a sam pomnik ważył 30 ton. Realizacja projektu trwała łącznie 4 lata, a jego koszt wyniósł 10 milionów euro. Część wydatków sfinansowały władze prawicowego rządu Macedonii, kierowanego przez premiera Nikolę Gruevskiego. Pomimo że przedsięwzięcie zostało skrytykowane przez opozycyjnych Socjaldemokratów, którzy przytaczali argumenty o stabej kondycji finansowej państwa, w dniu finalizacji projektu setki mieszkańców Skopje wypełniły Plac Macedoński. W momencie gdy pomnik Aleksandra Macedońskiego został posadowiony, Macedończycy zebrani w centrum stolicy wiwatowali i wznosili hasła: "Aleksander nareszcie wrócił do domu!"1. Jeden z mieszkańców w rozmowie z reporterem serwisu internetowego Balkan Insight stwierdzit: "Jestem bardzo podekscytowany. Również dlatego, że mam syna o imieniu Aleksander, który mieszka za granicą. Kiedy był mały, mówił "Jestem Aleksander Macedoński!»"2. Inna kobieta ze łzami w oczach stwierdziła: "To wielki ruch rządu”

Niepozorne wydarzenie uwydatniło stopień świadomości narodowej Macedończyków. Jednak należy zwrócić uwagę, że jeszcze w połowie XIX wieku poję-
Mgr Konrad Sebastian MORAWSKI jest absolwentem politologii na Uniwersytecie Rzeszowskim. konrad.morawski@wp.pl

Strona internetowa Balkan Insight, http://www.balkaninsight.com, "Macedonians Weep As Alexander Rises Over Skopje", 26.06.2011.

2 Ibidem.

3 Ibidem. 
cie "narodowość macedońska” nie było stosowane w powszechnym użyciu, a Macedończycy byli określani Bułgarami. Przemiany przełomu XIX i XX wieku w skomplikowanym procesie narodowotwórczym doprowadziły do wykształcenia się narodowości macedońskiej, która dopiero w 1991 roku uzyskała własne niezależne państwo. Proces kształtowania świadomości narodowej Macedończyków stanowi interesujący przedmiot analizy, szczególnie w odniesieniu do licznych zagrożeń destabilizujących jego przebieg. Niemniej, aby przejść do rozważań odnoszących się do kwestii macedońskiej, należało dokonać charakterystyki pojęcia narodu.

W tej materii szczególne ważne są rozważania Marka Waldenberga, który w pracy pt. Kwestie narodowe w Europie Środkowo-Wschodniej odrzucił popularne definicje narodu. Uznał je za niedoskonałe, gdyż nie uwzględniały one wszystkich aspektów odnoszących się do narodu. Autor zastąpił definicję narodu terminem model lub typ idealnego narodu 4 . Zgodnie z poglądami Marka Waldenberga na model narodu składają się następujące cechy:

„istnienie wspólnego języka; terytorium, na którym mieszka dana zbiorowość lub jej znaczna część i które uważa ona za swą ziemię ojczystą; dziedzictwo kulturowe, z którym znaczna część zbiorowości identyfikuje się jako z własnym; partycypowanie w kulturze narodowej; wspólna dość bogata symbolika i [...] wspólny zasób uczuć i myśli; przeświadczenie o wspólnym pochodzeniu etnicznym znacznej większości [...] zbiorowości; znaczne poczucie wspólnoty między ludźmi różnych klas i warstw społecznych; istnienie świadomości odrębności narodowej, poczucia bycia narodem; istnienie w przeszłości lub aktualnie państwa traktowanego jako swoje" 5

Zbiorowość, która spełniała wszystkie wymienione cechy można było określić mianem modelu narodu klasycznego. Natomiast im mniej cech spełniała określona zbiorowość, tym w mniejszym stopniu można ją było traktować w kategoriach modelu narodu klasycznego, a nawet - przy niespełnieniu większości cech - jako narodu.

Od przełomu XIX i XX wieku do drugiej połowy XX wieku w trwającym procesie kształtowania świadomości narodowej Macedończyków wykształciły się cechy, które w myśl rozważań Marka Waldenberga pozwoliły określić ludność macedońską mianem narodu.

\section{ANALIZA PROCESU KSZTALTOWANIA SIĘ I STABILIZACJI NARODU MACEDOŃSKIEGO}

W okresie od VI do VIII wieku naszej ery na terytorium Półwyspu Bałkańskiego osiedliła się grupa Słowian, określanych mianem Południowych. Na terytorium Starożytnej Macedonii wyodrębnity się strefy wpływów pomiędzy Bizancjum oraz Imperium Osmańskim, a także pomiędzy poszczególnymi narodami południowosłowiańskimi, w tym przypadku pomiędzy Bułgarami oraz Serbami. W latach 976-1018 istniała niezależna Macedonia, która w pierwszej połowie IX wieku, znajdując się w granicach Bułgarii, uległa chrystianizacji. Po uzyskaniu samodzielności w 976 roku państwo macedońskie przetrwało zaledwie 42 lata, po czym znalazło się pod panowaniem Bizancjum. Następnie władzę nad Macedonią sprawowały: Bułgaria do 1260 roku, Serbia w latach 1260-1389, Imperium Osmańskie w latach 1389-1878, pozostająca w zależności od Imperium Osmańskiego Bułgaria w latach 1878-1918 oraz państwa jugosłowiańskie w formie Królestwa Serbów,

$\bullet \bullet$

4 M. Waldenberg, Kwestie narodowe w Europie Środkowo-Wschodniej, Warszawa 1992, s. 14-16.

5 Ibidem, s. 17 
Chorwatów i Słoweńców6 w latach 1918-1941 oraz Demokratycznej Federacyjnej Jugosławii ${ }^{7}$ w latach 1945-1991.

Należy zwrócić uwagę, że Macedonia, która w 1918 roku weszła w skład państwa jugosłowiańskiego stanowiła tylko część Starożytnej Macedonii, określanej jako Macedonia Wardarska. Pozostałe terytoria Starożytnej Macedonii na mocy przeobrażeń, jakie dokonały się podczas wojen bałkańskich, znalazły się w posiadaniu Grecji, która przejęła tzw. Macedonię Egejską, oraz Bułgarii, do której granic została włączona tzw. Macedonia Piryńska. Po uzyskaniu przez Macedonię niepodległości w 1991 roku terytoria Macedonii Egejskiej i Piryńskiej nie powróciły do państwa i w efekcie stanowiły jedną z płaszczyzn konfliktów z Butgarią i Grecją.

W myśl definicji Marka Waldenberga ludności zamieszkującej Macedonię aż do przełomu XIX i XX wieku nie można było określić jako odrębnego narodu. Poczucie świadomości narodowej Macedończyków zaczęło się wykształcać pod koniec XIX wieku w toku skomplikowanego procesu. Można wyróżnić dwa zasadnicze etapy procesu kształtowania świadomości narodowej Macedończyków. Pierwszy nastąpił w okresie, w którym Macedonia funkcjonowała $w$ ramach państwa bułgarskiego, a drugi pod koniec lat osiemdziesiątych XX wieku, kiedy Macedonia należała do SFR Jugosławii.

Według Ewy Bujwid-Kurek „dopiero na przełomie XIX i XX w. nastąpił wzrost świadomości narodowej Macedończyków"8. Autorka zwróciła uwage na powstanie w 1893 roku Wewnętrznej Macedońskiej Organizacji Rewolucyjnej [dalej: VMRO], która w początkowych latach działalności stanowiła płaszczyznę współpracy bułgarskiej i macedońskiej. Organizacja została założona przez inteligentów z Bułgarskiej Męskiej Szkoły Wyższej w Salonikach pod nazwą Macedońskiej Organizacji Rewolucyjnej [dalej: MRO] i była wyrazem ruchu antytureckiego, który dążył do ograniczenia wpływów Imperium Osmańskiego na terenie Bułgarii. MRO wykazywała również ambicje związane z wyzwoleniem i zjednoczeniem wszystkich Słowian spod panowania tureckiego, w tym tzw. Słowian Tureckich. W następstwie wojen bałkańskich oraz podziału Macedonii profil organizacji uległ zmianie, a z jej struktur wyodrębniły się nowe organizacje. W Macedonii Wardarskiej wykształciła się VMRO, skupiona na walce o uniezależnienie i zjednoczenie wszystkich terytoriów macedońskich.

Inną rolę w procesie kształtowania świadomości narodowej Macedończyków odegrali inteligenci macedońscy na czele z Krste Petkovem Misirkovem, który w licznych publikacjach postulował niezależność Macedonii. Jeden z najwybitniejszych Macedończyków zaproponował pod koniec XIX wieku rozwiązanie spornej kwestii bułgarsko-macedońskiej. Zgodnie z poglądami Misirkova istniały odrębne narody Bułgarów, Macedończyków oraz tzw. Macedończyków-Bułgarów. Naród macedoński powinien posiadać własne niezależne państwo, a Macedończycy-Bułgarzy powinni mieć prawo do decydowania o przynależności do Bułgarii lub Macedonii. Działalność Krste Petkova Misirkova przyczyniła się również do wykształcenia i utrwalenia literackiego języka macedońskiego, który stanowił kolejny atrybut odrębności wobec Bułgarii. Praca autora pt. Za makedonski raboti (W sprawach macedońskich) pełniła istotną rolę $\mathrm{w}$ procesie legitymizacji istnienia niezależnego narodu macedońskiego. Autor utworzył także pierwszy niezależny magazyn macedoński pt. Vardar, wydany w Odessie. Pomimo że ukazał się zaledwie jeden numer tego wy-

\section{......}

6 W wyniku przewrotu dokonanego przez króla Aleksandra Karađorđevića w 1929 roku nazwa Królestwa SHS została przemianowana na Królestwo Jugosławii.

7 Na mocy konstytucji federacyjnej z 7 kwietnia 1963 roku nazwa Demokratycznej Federacyjnej Jugosławii uległa zmianie na Socjalistyczną Federacyjną Republikę Jugosławii.

8 E. Bujwid-Kurek, Państwa pojugostowiańskie. Szkice politologiczne, Kraków 2008, s. 114. 
dawnictwa, jego znaczenie polegało na zasygnalizowaniu obecności Macedończyków na arenie międzynarodowej.

Po przemianach w drugiej dekadzie XX wieku Macedonia Wardarska została włączona w granice Królestwa SHS, ale zarówno rewolucyjna działalność VMRO, jak i literacka i naukowa Krste Petkova Misirkova przyczynity się do wzrostu świadomości narodowej Macedończyków. Wymienione środowiska zrzeszały Macedończyków z Bułgarii, Grecji oraz pozostałych terytoriów, a także bez wątpienia przyczyniły się wykształcenia się cech niezależnego narodu macedońskiego.

Po II wojnie światowej Macedonia została włączona do SFR Jugosławii. O ile w takich republikach federacji jak Chorwacja i Słowenia wykształciły się dążenia związane z uzyskaniem niepodległości, o tyle przynależność Macedonii do Jugosławii pod rządami Tito była dla republiki korzystna. Wszak Macedonia była republiką biedną, a federacja udzielała jej pomocy finansowej. Jacek Wojnicki przytoczył dane, które świadczyły o poprawie sytuacji ekonomicznej w Macedonii w okresie przynależności do federacji: „zwiększył się udział przemysłu w strukturze wytwarzania (z 15 do 54\%), zmalał udział rolnictwa (z 58 do 17\%), zwiększył się udział handlu (z 8 do 12\%)"9. Poza tym przynależność Macedonii do federacji ochraniała państwo przed ingerencją ze strony Bułgarii oraz Grecji, które wyrażały aspiracje do zagarnięcia terytoriów Macedonii. Nie bez znaczenia dla utrzymania Macedonii w granicach SFR Jugosławii była także rola czołowego komunistycznego działacza macedońskiego Lazara Koliševskiego ${ }^{10}$, który cieszył się dużym zaufaniem Josipa Broza Tito.

W okresie przynależności Macedonii do SFR Jugosławii w państwie nastąpił drugi etap kształtowania świadomości narodowej Macedończyków, który paradoksalnie polegał na wzmacnianiu przez władze federacyjne poczucia odrębności narodu macedońskiego. Działania Tito i jego współpracowników były odpowiedzią na politykę Bułgarii oraz Grecji w stosunku do Macedonii, która polegała na głoszeniu przynależności narodu macedońskiego do narodu bułgarskiego lub greckiego. Władze federacyjne Jugosławii - znając zły stan finansowy Macedonii - były przekonane, że dla republiki świadomej swojej odrębności korzystniejsze będzie pozostanie w granicach federacji. Wyrazem działań, które polegały na wzmacnianiu odrębności narodowej Macedończyków było m.in. nadanie niezależności prawosławnemu Kościołowi Macedonii. Innym istotnym aspektem kształtowania narodu macedońskiego był wpływ działalności Dragana Bogdanovskiego, który od połowy lat osiemdziesiątych XX wieku wydawał na emigracji czasopismo pt. „Makedonska nacija" (Naród Macedoński), utrwalające obecność Macedonii na arenie międzynarodowej.

Jednak wpływ wydarzeń w Chorwacji i Stowenii oraz tendencje destabilizacyjne, które zostały zapoczątkowane $\mathrm{w}$ federacji po śmierci Tito $\mathrm{w}$ latach osiemdziesiątych $\mathrm{XX}$ wieku wpłynęły na decyzję Macedończyków o podjęciu działań związanych z wystąpieniem z federacji. Sam proces odłączenia Macedonii od SFR Jugosławii przebiegł sprawnie i bez komplikacji, jakie pojawiły się w innych republikach. Świadomi swojej odrębności Macedończycy 17 listopada 1991 roku proklamowali własne niezależne państwo. Po uzyskaniu przez Macedonię niepodległości znalazło się ono w niekorzystnej sytuacji geopolitycznej. Macedonia po 1991 roku graniczyła na zachodzie z Albanią, na północy z Federalną Republiką Jugosławiii" ${ }^{11}$ na wschodzie z Bułgarią, a na południowym wscho-

\section{......}

9 J. Wojnicki, Proces instytucjonalizacji przemian ustrojowych w państwach postjugosłowiańskich, Pultusk 2007, s. 138.

10 Lazar Koliševski sprawował najwyższe urzędy w Macedonii. Do 1953 roku był premierem, a do 1962 roku prezydentem republiki Macedonii. Do 1963 roku sprawował urząd przewodniczącego Związku Komunistów Macedonii, a przed śmiercią w maju 1980 roku Tito wyznaczył go na prezydenta SFRJ.

11 Od 2008 roku na północnej granicy Macedonii istniały Kosowo oraz Serbia. W 2003 roku rozpadała się Federalna Republika Jugosławii. Na jej miejsce została powołana Serbia i Czarnogóra, która w tej formie prze- 
dzie i na południu z Grecją. Każdy z sąsiadów Macedonii wyrażał różnego typu pretensje wobec tego państwa.

Rząd w Skopje w trudnej sytuacji politycznej uchwalit podstawowe akty prawne, w tym konstytucję z 20 listopada 1991 roku, które prawnie legitymizowały istnienie Macedonii. Niemniej zarówno wobec nazwy Macedonia, jak i w stosunku do symboli narodowych państwa pretensje wyraziła Grecja, która, według Piotra Eberharda, uważała się za "spadkobierczynię tradycji starożytnej helleńskiej Macedonii"12. Grecy żądali zmiany nazwy państwa na Republika Skopje, rezygnacji z symboli nawiązujących do Starożytnej Macedonii oraz deklaracji ze strony rządu macedońskiego o braku roszczeń terytorialnych do północnej części Grecji, licznie zamieszkiwanej przez mniejszość macedońską. Wraz z ich żądaniami pojawiły się również działania polegające na nałożeniu embargo gospodarczego oraz blokowaniu akcesji Macedonii do instytucji europejskich i światowych. Pomimo podpisania 13 września 1995 roku tymczasowego porozumienia o normalizacji wzajemnych stosunków, napięcia macedońsko-greckie utrzymywały się w późniejszych latach.

Bułgaria była pierwszym państwem, które uznało niepodległość Macedonii, ale demokratyczny rząd państwa bułgarskiego określił Macedończyków jako odłam narodu bułgarskiego. Pomiędzy państwami wyniknął też konflikt odnoszący się do języka macedońskiego. Rząd Bułgarii sformułował stanowisko, że język macedoński należało traktować jako dialekt bułgarskiego, a w oficjalnym użyciu powinien być nazywany bułgarsko-macedońskim. Niezależnie od poglądów ideologicznych zarówno władze demokratycznej Bułgarii po 1989 roku, jak i komunistycznej w okresie 1944-1999 uznawały Macedończyków za odłam narodu bułgarskiego. Kwestia roszczeń bułgarskich miała również wpływ na konflikt Macedonii z Serbią, który odnosił się kwestii religijnych. Cerkiew Serbska domagała się od Cerkwi Macedońskiej rezygnacji z autokefalii, które właśnie z powodu ekspansywnej polityki Bułgarii zostały nadane Macedonii w okresie przynależności do SFR Jugosławii.

Inną naturę miał konflikt Macedończyków z Albanią i Kosowem. Można było wyróżnić dwa wymiary tego konfliktu. Pierwszy był związany z postępującym wzrostem liczby mniejszości albańskiej w Macedonii. Na podstawie badań Piotra Eberhardta można przyjąć, że w 1994 roku Albańczycy stanowili 22,9\% ogólnej ludności Macedonii, a już w 2002 roku ich liczba wynosiła 25,2\% ogólnej liczby ludności Macedonii13. Duża i dobrze zorganizowana społeczność domagała się od rządu Macedonii przyznania jej licznych praw społecznych i politycznych, w tym uznania jej za drugi naród Macedonii. Natomiast drugi wymiar konfliktu był związany z uzyskaniem przez Kosowo niepodległości w 2008 roku. Były okręg autonomiczny Serbii w 2007 roku zamieszkiwało 92\% Albańczyków. Należy zwrócić uwage, że położenie Macedonii na północnej granicy z Kosowem i na zachodniej granicy z Albanią nie było korzystne dla państwa macedońskiego w perspektywie utrzymania jedności terytorialnej. Zresztą już na początku lat dziewięćdziesiątych XX wieku ludność mieszkająca przy granicy z Albanią i Kosowem (ówcześnie należącym do Federalnej Republiki Jugosławii) domagała się niezależności. Wynikiem dążeń albańskich było porozumienie z rządem Macedonii podpisane 13 sierpnia 2001 roku w Ochrydzie, którego założenia nadały określone przywileje dla Albańczyków, w tym m.in. ustanowienie stałych miejsc $w$ jednostkach samorządu terytorialnego oraz uznanie za oficjalny języka albańskiego w jednostkach terytorialnych Macedonii, w których liczba Albańczyków wynosiła powyżej 20\% ogółu ludności.

trwała do 2006 roku, a na jej miejscu powstały dwa samodzielne państwa: Czarnogóra oraz Serbia. W 2008 roku z granic Serbii odłączyło się Kosowo.

12 P. Eberhardt, Przemiany demograficzno-etniczne na obszarze Jugostawii w XX wieku, Lublin 2005, s. 145.

13 Ibidem, s. 146-150. 
Wpływ zagrożeń zewnętrznych oraz wzrastające żądania Albańczyków mieszkających w Macedonii doprowadziły do wykształcenia się społecznego poczucia niepewności Macedończyków w odniesieniu do utrzymania ustabilizowanego państwa. Następstwem tego zjawiska była mobilizacja elektoratu partii prawicowych, w tym przede wszystkim Wewnętrznej Macedońskiej Organizacji Rewolucyjnej-Demokratycznej Partii Jedności Narodowej [dalej: VMRO-DPMNE], która w historii postjugosłowiańskiej Macedonii wygrywała 4 spośród 6 elekcji parlamentarnych. Partia określona przez Michała Jerzego Zachariasa jako narodowa ${ }^{14}$ stanowiła gwarancję realizowania polityki oporu wobec roszczeń państw zewnętrznych.

\section{KONKLUZJE}

Proces kształtowania świadomości narodowej Macedończyków można podzielić na dwa zasadnicze etapy. W pierwszym, który miał miejsce na przełomie XIX i XX wieku, wykształciły się przesłanki związane z wyposażeniem Macedończyków w tożsamość narodową. Powołując się na rozważania Marka Waldenberga, zauważmy, że w pierwszym etapie kształtowania świadomości narodowej Macedończyków wyodrębniły się język macedoński, wspólny zasób uczuć i myśli polegający na dążeniu do utworzenia własnego niezależnego państwa, poczucie odrębności narodowej, przeświadczenie o wspólnym pochodzeniu etnicznym oraz nawiązanie do istniejącego $\mathrm{w}$ przeszłości państwa macedońskiego. W drugim okresie kształtowania świadomości narodowej Macedończyków, który miał miejsce w czasach przynależności Macedonii do SFR Jugosławii, wykształciły się przeświadczenie o przynależności do konkretnego terytorium, identyfikacja społeczna z konkretną symboliką, a także z określonym zasobem dziedzictwa kulturowego i religijnego. Należy zwrócić uwage, że w obu przypadkach Macedonia była pod panowaniem obcych państw: Bułgarii, zależnej od Imperium Osmańskiego, oraz SFR Jugosławii.

Po uzyskaniu przez Macedończyków po 973 latach (!) własnego i niezależnego terytorium, w państwie pojawiły się liczne problemy zagrażające jego jednolitości. Roszczenia wobec Macedonii wyrażały Albania, Bułgaria, Grecja, Kosowo oraz Serbia. W państwie wykształciło się poczucie niepewności społecznej związanej z zagrożeniami destabilizującymi jedność terytorialną Macedonii. Nie powinny zatem dziwić wyniki wyborów parlamentarnych w Macedonii z początku czerwca 2011 roku, które niemal z 40\% poparciem wygrała konserwatywno-nacjonalistyczna VMRO-DPMNE, a zatem partia nawiązująca do organizacji mającej wielki zasługi w procesie kształtowania narodu macedońskiego.

14 M.J. Zacharias, Komunizm. Federacja. Nacjonalizmy. System władzy w Jugosławii 1943-1991, Warszawa 2004, s. 496. 


\section{Summary}

The analysis has taken into account two main stages of developing national identity of the Macedonians which were the basis for obtaining their own independent state. The first stage of developing national identity of the Macedonian Nation, which took place at the turn of the 20th century, was connected with activities of Macedonian intellectuals and the Internal Macedonian Revolutionary Organization. However, in the second stage of developing national identity of the Macedonians, which took place in the second half of the 20th century (when Macedonia was part of the Socialist Federal Republic of Yugoslavia), the authorities of the Yugoslavian federation paradoxically played an important role as they were maintaining a sense of national autonomy among the people of Macedonia. After gaining independence by Macedonia in November 1991, destabilising moods developed in the state. Those moods were influenced primarily by the countries neighbouring with Macedonia and by Albanian minorities in Macedonia. The complex geopolitical situation of the independent Macedonia had a stimulating influence on consolidation of national identity of the Macedonians and contributed to increasing the importance of national factions in the state.

Keywords: Macedonia, Macedonian Nation, Socialist Federal Republic of Yugoslavia 